\title{
An Evidence-to-Practice Review on the Efficacy of Instrument Assisted Soft Tissue Mobilization
}

Matthew G. Moore, SCAT, ATC; Aneika R Daley, SCAT, ATC; and Zachary Winkelmann, PhD, SCAT, ATC

University of South Carolina, Columbia, SC

\begin{abstract}
Instrument assisted soft tissue mobilization (IASTM) is the use of specially designed instruments that provide a mobilizing effect to soft tissue to help with decreasing pain and improving range of motion. Over the years, there has been an increase in the use of IASTM as well as an increase in research for its effects on soft-tissue injuries, range of motion (ROM), and pain management; however, the results have not been supported as a whole. Evidence for the positive outcomes from the use of IASTM, in conjunction with therapeutic exercise or other interventions, has been lacking in many studies. As a result, clinicians question its effectiveness. The purpose of this evidence-to-practice review was to summarize the results of the systematic review and apply it to clinical practice. The authors of the guiding systematic review aimed to investigate the current state of available literature on the topic of IASTM, specifically using studies that compared IASTM pre \& post-treatment and compared the IASTM group to other intervention or control groups. Seven total studies were included in the final review, and of those, five focused on IASTM treatment for musculoskeletal pain and two focused on IASTM treatment for joint ROM. Each study varied in methodology, interventions, treatment times, and outcome measures. Therefore, the systematic review was unable to make a direct comparison between all studies and results were deemed inconclusive. In conclusion, using IASTM as a stand-alone treatment is not recommended in any case. However, in the event the treatment is not contraindicated and the clinician is inclined to use the treatment for physiological improvement, then implementation and use of IASTM is not unreasonable and could potentially benefit the patient when used in conjunction with therapeutic exercise or other form of treatment.
\end{abstract}

\section{Key Phrases}

Therapeutic devices, rehabilitation, clinician-rated outcomes

\section{Correspondence}

Dr. Zachary Winkelmann, University of South Carolina

1300 Wheat Street, Columbia, SC 29208.

E-mail:winkelz@mailbox.sc.edu

Twitter: @zachwinkelmann

\section{Full Citation}

Moore MG, Daley AR, Winkelmann ZK. An evidence-topractice review on the efficacy of instrument assisted soft tissue mobilization. Clin Pract Athl Train. 2020;3(3):4-1 1. https://doi.org/10.31622/2020.0003.3.2.

Submitted: April 20, 2020 Accepted: September 1, 2020

Copyright (C) by Indiana State University All rights reserved. ISSN Online 2577-8188

\section{ORIGINAL REFERENCE AND SUMMARY}

Cheatham SW, Lee M, Cain M, Baker R. The efficacy of instrument assisted soft tissue mobilization: a systematic review. Journal of the Canadian Chiropractic Association. 2016;60(3):200-211.

\section{SUMMARY}

\section{CLINICAL PROBLEM AND QUESTION}

Soft tissue injuries are common among the general and athletic populations and these injuries can lead to acute and chronic loss of function, adhesions, and pain. ${ }^{2-4}$ Instrument assisted soft tissue mobilization (IASTM) is the use of specially designed instruments that provide a mobilizing effect to soft tissue to help with decreasing pain and improving range of motion (ROM).2-4 Over the years, IASTM has become a popular treatment for soft tissue injuries involving myofascial restrictions and in increasing pain thresholds. ${ }^{5}$ This therapy has been utilized over a variety of different treatment areas, almost all of which involving a musculoskeletal injury or pathology. ${ }^{2-4}$

During the healing process of an injury or pathology, the human body will respond with an initial inflammatory response, followed by a proliferation phase, and then finally maturation of the new tissue. During these last two phases, IASTM is traditionally utilized as an intervention/modality in order to aid the realignment of tissue, collagen elasticity, and increase perfusion of tissues to promote healing. ${ }^{2}$ Studies have been conducted to investigate the effect of IASTM on patient ROM and pain. $2,4,5$ Results of these studies lack 
definitive findings in almost all cases, and in turn, many clinicians have been using IASTM without truly understanding the outcomes of the technique. Therefore, the purpose of this review was to assess the clinical effectiveness and efficacy of IASTM as a treatment protocol.

\section{SUMMARY OF LITERATURE}

The authors conducted a systematic search for studies/clinical trials using IASTM through the databases of PubMed, PEDro, Science Direct, the EBSCOhost collection, and hand searching known journals. Studies that were included in the review had to meet the following criteria: 1) peer reviewed, English language publications, 2) controlled clinical trials that compared pre- and post-test measurements for an intervention data extraction and synthesis program using IASTM, 3) investigations that compared an intervention program using IASTM, and 4) investigations that compared two intervention programs using IASTM. The search identified 261 articles, plus two others identified through other sources, for initial review. After duplicates were removed and records were screened, 47 full-text articles were reviewed for inclusion. After review, seven articles were included in the qualitative synthesis.

\section{SUMMARY OF INTERVENTIONS}

Of the articles synthesized (Table 1), six articles examined the Graston Technique ${ }^{\circledR}$ and one examined the Fascial Abrasion Technique ${ }^{\circledR}$. Five studies investigated the effects of IASTM on the patients' pain from a musculoskeletal pathology, while two studies examined the effect of IASTM on the ROM in healthy individuals. For the five studies that focused on IASTM treatment for patients with pathology, the interventions in each study differed so it was difficult to determine which resulted in a better outcome. Two studies focused on comparing IASTM with a control group, one to treat patients classified with lateral epicondylitis ${ }^{6}$ and the other to treat the upper

Copyright $\left({ }^{2}\right.$ by Indiana State University All rights reserved. ISSN Online 2577-8188 back.7 One study compared IASTM with soft-tissue massage to treat patients with carpal tunnel syndrome ${ }^{8}$ and one study compared two different intervention programs that included IASTM, strengthening exercises, stretching, and chiropractic manipulative therapy to treat patients with patellofemoral pain syndrome. ${ }^{9}$ The final study compared three intervention programs including IASTM, dynamic strengthening, or proprioception exercises to treat patients with chronic ankle instability. ${ }^{10}$ All studies that used Graston Technique ${ }^{\circledR}$ had a timeframe for interventions ranging from 2-6 weeks. Only one study followed the recommended Graston Technique ${ }^{\circledR}$ protocol with other studies modifying it or not including all components of intervention in their reported methods.

The two studies that focused on IASTM treatment for joint ROM measured the effects of the treatment on ROM of the shoulder and knee in healthy subjects. The study focusing on the shoulder measured the difference in glenohumeral ROM after a single session of Graston Technique ${ }^{\circledR}$ treatment with an experimental and nonintervention control group. ${ }^{11}$ The other study compared the effects of one session of IASTM following the Fascial Abrasion Technique ${ }^{\circledR}$ and one session of foam rolling. ${ }^{11}$ The Graston Technique ${ }^{\circledR}$ protocol was not followed in the first study and no specific IASTM protocol was used in second study. From these two studies we can see that IASTM was able to increase ROM over control group, so IASTM could possibly be a tool used for increasing ROM, however, further research is needed to validate this.

\section{SUMMARY OF OUTCOMES}

The five studies that focused on IASTM as treatment for musculoskeletal pathologies included a combination of patient-reported and clinical-rated outcome measures (Table 1). The most common patient-reported outcome used was the Visual Analog Scale for pain. All studies 
measured outcomes pre-intervention and immediately post-intervention. Three studies reported a second follow-up, which ranged between 2-3 months post-treatment. The two studies using IASTM as treatment for joint ROM both used joint ROM, measured with a digital inclinometer, as the primary outcome measure. There were no patient-reported outcome measures used in those studies, but they both measured pre-intervention and immediately postintervention outcomes. The study that followed the Fascial Abrasion Technique ${ }^{\circledR}$ was the only method to conduct a 24-hr post-intervention follow-up assessment.

\section{FINDINGS AND CLINICAL IMPLICATIONS}

Each study varied in methodology, interventions, treatment times, and outcome measures (Table 1) and therefore, the systematic review was unable to make a direct comparison between all studies and results were deemed inconclusive. Out of the 7 articles included in the systematic review, Graston Technique ${ }^{\circledR}$ was the most common form of IASTM used, only one study did not use Graston Technique ${ }^{\circledR}$. However, the recommended treatment protocol was only followed by one of the six studies, while others had their own variation, which may have been a contributing factor to the inconsistent results across the studies. The studies examined in the review, along with their methods and outcomes, can be seen in Table 1. The differences in the protocols followed by each study also deemed the results insignificant in determining the effectiveness of Graston Technique ${ }^{\circledR}$ because the specified Graston Technique ${ }^{\circledR}$ protocol was not followed. Due to the variability in the study protocols (which includes methodology, interventions, and outcome measures), it was difficult to determine the best treatment protocol. Clinicians conducting future research should consider what technique they are utilizing and differentiate if the technique chosen followed the manufactures' specific treatment

Copyright $\left({ }^{\circ}\right.$ by Indiana State University All rights reserved. ISSN Online 2577-8188 protocols, or if just the tools or general treatment method was used.

From this systematic review, evidence does not support the efficacy of IASTM for treating certain musculoskeletal pathologies and is weak in supporting effectiveness of IASTM for increasing lower extremity joint ROM as a standalone treatment. Though IASTM is a form of myofascial therapy, there is a lack of evidence to support its use or validation. As a result of this, there still lies a gap between the current research and clinical practice. However, IASTM may have a degree of clinical utility due to each study individually identified improvements for their outcome measures. Clinicians should be tentative in the use of IASTM since it has not been validated; however it may still be used clinically paired with another treatment to help improve patient-reported outcomes, barring any contraindications. Future research should focus on testing specific IASTM protocols, with uniformity in methodology, interventions, and outcome measures, to validate its use.

\section{CLINICAL BOTTOM LINE}

The guiding systematic review suggests that IASTM lacks the efficacy to positively support its use in myofascial treatment. While IASTM was found to not have good efficacy, depending on the patient, it may help improve outcomes of acute joint ROM (Table 1).11 In order to implement IASTM clinically to have the best possible results, it is recommended that the clinician follow the specific IASTM treatment protocols provided by the manufacturer and to ensure the patient does not have any contraindications for the treatment. If a clinician were to implement IASTM into a treatment, it is always important to consider the patient population that is undergoing the treatment as well as the patient presentation. In the case of working with patients that are minors, parent/guardian education and consent should 
always be considered, especially if the treatment results in adverse effects such as visible bruising, ecchymosis, petechiae, or inflammation. When treating the geriatric patient population, it is important to consider their current health status and the ability of their bodies to withstand and recover from this type of treatment. In order to maintain consistent quality and standard of IASTM treatment, it is recommended that clinicians utilizing IASTM receives training in the application and administration of the treatment, and specialized training should be at the discretion of the clinician or the clinician's employer. To conclude, IASTM has not been shown to have adequate efficacy, and using IASTM as a standalone treatment is not recommended. Based upon the results of current literature, IASTM was not an effective intervention for certain musculoskeletal pathologies and further research is necessary to better understand the clinical effect of this intervention.

\section{REFERENCES}

1. Cheatham SW, Lee $M$, Cain M, Baker R. The efficacy of instrument assisted soft tissue mobilization: a systematic review. J Can Chiropr Assoc. 2016; 60(3):200-211.

2. Kim J, Sung DJ, Lee J. Therapeutic effectiveness of instrument-assisted soft tissue mobilization for soft tissue injury: mechanisms and practical application. J Exerc Rehabil. 2017; $13(1): 12-22$. https://doi.org/10.12965/ier.1732824.41 2.

3. Stow R. Instrument-Assisted Soft Tissue Mobilization. Int J Athl Ther Train. 2011; 16(3):5-8. https://doi.org/10.1123/ijatt.16.3.5.

4. Ikeda N, Otsuka S, Kawanishi Y, Kawakami Y. Effects of Instrument-assisted Soft Tissue Mobilization on Musculoskeletal Properties. Med Sci Sports Exerc. 2019; 51(10):21662172.

Copyright $\left({ }^{\circ}\right.$ by Indiana State University All rights reserved. ISSN Online 2577-8188
https://doi.org/10.1249/MSS.0000000000 002035.

5. Gulick DT. Instrument-assisted soft tissue mobilization increases myofascial trigger point pain threshold. J Body Mov Ther. 2018; 22(2):341-345.

https://doi.org/10.1016/i.jbmt.2017.10.01 2 .

6. Blanchette MA, Normand MC. Augmented Soft Tissue Mobilization vs Natural History in the Treatment of Lateral Epicondylitis: A Pilot Study. J Manipulative Physiol Ther. 2011 ; 34(2): $123-130$. https://doi.org/10.1016/i.impt.2010.12.00 1 .

7. Gulick DT. Influence of instrument assisted soft tissue treatment techniques on myofascial trigger points. J Bodyw Mov Ther. 2014; 18(4):602-607. https://doi.org/10.1016/i.jbmt.2014.02.00 4.

8. Burke J, Buchberger DJ, Carey-Loghmani MT, Dougherty PE, Greco DS, Dishman JD. A pilot study comparing two manual therapy interventions for carpal tunnel syndrome. J Manipulative Physiol Ther. 2007; 30(1):50-61. https://doi.org/10.1016/i.impt.2006.11.01 4.

9. Brantingham JW, Globe GA, Jensen $M L$, et al. A feasibility study comparing two chiropractic protocols in the treatment of patellofemoral pain syndrome. J Manipulative Physiol Ther. 2009; 32(7):536-548. https://doi.org/10.1016/i.impt.2009.08.00 5.

10. Schaefer JL, Sandrey MA. Effects of a 4Week Dynamic-Balance-Training Program Supplemented With Graston InstrumentAssisted Soft-Tissue Mobilization for Chronic Ankle Instability. J Sport Rehabil. 2012; $21(4): 313-326$.

https://doi.org/10.1123/isr.21.4.313.

11. Laudner K, Compton BD, McLoda TA, Walters CM. Acute effects of instrument assisted soft tissue mobilization for improving posterior

Clinical Practice in Athletic Training Volume 3 - Issue 3 - November 2020 
shoulder range of motion in collegiate baseball players. Int J Sports Phys Ther. 2014; 9(1): 1-7.

12. Markovic G. Acute effects of instrument assisted soft tissue mobilization vs. foam rolling on knee and hip range of motion in soccer players. J Bodyw Mov Ther. 2015; 19(4):690-696.

https://doi.org/10.1016/i.jbmt.2015.04.01

$\underline{0}$. 
Table 1. Summary of Studies ${ }^{1}$

\begin{tabular}{|c|c|c|c|c|c|c|}
\hline Study & Pathology & Intervention & $\begin{array}{l}\text { Outcome } \\
\text { Measures }\end{array}$ & $\begin{array}{c}\text { Graston } \\
\text { Technique }^{\circledR} \\
\text { Used }\end{array}$ & $\begin{array}{c}\text { Graston } \\
\text { Technique }^{\circledR} \\
\text { Protocol } \\
\text { Followed }\end{array}$ & Results \\
\hline $\begin{array}{l}\text { Blanchette } \\
\text { and } \\
\text { Normand } 6\end{array}$ & Lateral Epicondylitis & $\begin{array}{l}\text { - IASTM: Twice a week for } 5 \\
\text { weeks } \\
\text { - Control: Education, computer } \\
\text { ergonomics, stretching exercise, } \\
\text { ice, and anti-inflammatory } \\
\text { medication }\end{array}$ & $\begin{array}{ll}\text { - } & \text { VAS } \\
\text { - } & \text { Pain rated } \\
\text { evaluation } \\
\text { - } & \text { Grip strength }\end{array}$ & Yes & No & $\begin{array}{l}\text { - Post intervention and 3- } \\
\text { month follow-up: both } \\
\text { groups showed } \\
\text { improvement in all } \\
\text { outcome measures }\end{array}$ \\
\hline Burke et $\left.\mathbf{a}\right|^{8}$ & $\begin{array}{l}\text { Carpal Tunnel } \\
\text { Syndrome }\end{array}$ & $\begin{array}{l}\text { - IASTM:2x/week for } 4 \text { weeks, } \\
\text { 1x/week for } 2 \text { weeks } \\
\text { - Control: Soft tissue mobilization, } \\
2 x / \text { week for } 4 \text { weeks, } \\
1 x / \text { week for } 2 \text { weeks }\end{array}$ & - VAS & Yes & Yes & $\begin{array}{l}\text { - Post intervention and 3- } \\
\text { month follow-up: Both } \\
\text { groups showed } \\
\text { improvements in all } \\
\text { outcome measures }\end{array}$ \\
\hline Gulick $^{7}$ & $\begin{array}{l}\text { Myofascial Trigger } \\
\text { points in upper back }\end{array}$ & $\begin{array}{l}\text { - } 2 \text { Phases of IASTM: } 5 \mathrm{~min}, 6 \\
\text { treatments (2x/week for } 3 \\
\text { weeks) } \\
\text { - Control: no treatment }\end{array}$ & $\begin{array}{l}\text { - Pressure } \\
\text { sensitivity with } \\
\text { algometer }\end{array}$ & Yes & No & $\begin{array}{l}\text { - Post intervention: both } \\
\text { groups showed } \\
\text { improvements in } \\
\text { outcome measures } \\
\text { - No secondary follow-up } \\
\text { reported }\end{array}$ \\
\hline
\end{tabular}




\section{Laudner et}

al ${ }^{11}$
Posterior shoulder
muscle

- IASTM: 1 treatment, treatment time of 40 seconds

- Control: No Treatment

- IASTM: One treatment, 2 minutes each region Markovic12
Quadriceps and
Hamstrings

- Control: Foam Rolling, one session $2 \mathrm{x} / \mathrm{I}$ minute
- Glenohumeral

horizontal

adduction, and

internal

Yes

No

rotation of

motion

- Passive straight leg raise test

- Supine passive knee flexion test

\section{No (Fascial}

Abrasion

Technique $®$

used)

- Post intervention: IASTM group showed greater acute improvements in ROM compared to the control group

- No secondary follow-up reported

- Post intervention: both groups showed improvement in joint ROM

- 24-hour follow-up: IASTM group -> the most joint ROM

- IASTM: 2x/week, max of 8 min - VAS

- Control: 4-week balance program (single-limb hops to stabilization, hop to

- Foot and ankle ability

stabilization and reach, unanticipated hop to measure Schaefer and
Sandrey ${ }^{10}$$\quad \begin{aligned} & \text { Chronic Ankle } \\ & \text { Instability }\end{aligned}$

stabilization, single-limb stance activities)
- 4-way ankle ROM

- Star Excursion Balance Test
Yes

No
- Post-intervention: all groups showed improvement in all outcome measures

- No long-term follow-up reported 
- Chiropractic manipulative therapy, exercise

- Group 1: IASTM to knee joints only

Brantingham Patellofemoral Pain et $\mathbf{a l}^{\mathbf{9}}$
- Group 2: IASTM to lumbosacral, hip, knee, ankle, and foot

- Both groups received treatment 1-3x/week for 2-6 weeks,

total of 6 treatments
- VAS

- Anterior knee pain scale

- Patient

Yes satisfaction scale
- Post-intervention and 2month follow-up: both groups showed

improvement in all outcome measures

\footnotetext{
VAS $=$ Visual Analog Scale; IASTM $=$ Instrument Assisted Soft Tissue Mobilization
} 